Jurnal Konstruksi Hukum | ISSN: 2746-5055

Vol. 2, No. 3, September 2021 Hal. 563-568 | Tersedia online di

https://www.ejournal.warmadewa.ac.id/index.php/jukonhum

DOI:https://doi.org/ 10.22225/jkh.2.3.3642.563-568

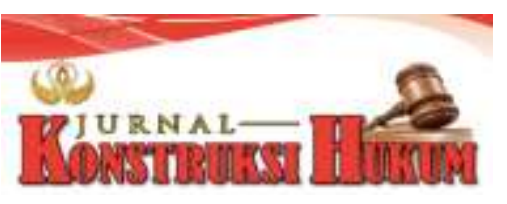

\title{
PERBANDINGAN KEKUATAN HUKUM ALAT BUKTI OTENTIK DAN PERJANJIAN BAWAH TANGAN (Studi Kasus Perkara Nomor: 939/Pdt.C./2818/PN Dps)
}

\author{
I Made Indra Udayana, Made Minggu Widyantara, Ni Made Sukariyati Karma \\ Fakultas Hukum, Universitas Warmadewa, Denpasar - Bali, Indonesia \\ Mingguwidyantara.fhwjurnal@gmail.com
}

\begin{abstract}
Abstrak
Hukum adalah peraturan hidup yang mengatur kehidupan manusia dalam masyarakat, sebagai peraturan hidup maka hukum itu berfungsi membatasi kepentingan dari setiap pendukung hukum (subyek hukum), menjamin kepentingan, dan hak-hak mereka masing-masing. Tujuan dari penelitian ini adalah untuk mengetahui perbandingan kekuatan hukum alat bukti akta otentik dengan akta bawah tangan, serta untuk mengetahui pertimbangan hakim dalam putusannya atas kekuatan hukum akta bawah tangan yang mengalahkan akta otentik. Penelitian ini merupakan tipe penelitian hukum normatif yang dilakukan dengan metode pencatatan dan pengkajian berdasarkan bahan-bahan hukum, sedangkan pendekatan masalah yang digunakan pendekatan peraturan perundang-undangan dan konsepsual. Sumber data yang diperolah dari penelitian ini yakni dengan mencari informasi yang akurat dengan mempelajari gejala masyarakat guna mendapatkan data yang sebenar-benarnya, dengan demikian data yang diperoleh dapat digabungkan dengan beberapa referensi buku hukum yang berkaitan dengan penelitian. Hasil penelitian menunju kan bahwa perbandingan kekuatan hukum alat bukti akta otentik dengan akta bawah tangan yaitu aktanya dibuat oleh maupun dihadapan pejabat yang berwenang untuk itu didalam wilayah kerjanya sebagaimana diatur dalam undang-undang serta merupakan alat bukti yang sempurna sebagaimana terdapat dalam Pasal 1870 K UHPer.

Kata kunci: Akta Bukti Otentik, Perbandingan Hukum, Perjanjian Bawah Tangan

Abstract

Law is a rule of life that regulates human life in society, as a rule of life, the law functions to limit the interests of each legal supporter (legal subject), guaranteeing their respective interests and rights. The purpose of this study is to determine the comparison of the legal strength of authentic deed evidence with private deed, as well as to determine the judge's considerations in his decision on the legal strength of private deed which defeats authentic deed. This research is a type of normative legal research conducted by recording and reviewing methods based on legal materials, while the problem approach uses a statutory and conceptual approach. The source of the data obtained from this research is by looking for accurate information by studying the symptoms of the community in order to get the actual data, thus the data obtained can be combined with several legal book references related to research. The results of the study show that the comparison of the legal strength of authentic deed evidence with an underhand deed, namely the deed is made by or before an authorized official in his working area as regulated by law and is perfect evidence as contained in Article $1870 \mathrm{~K}$ UHPer.
\end{abstract}

Keywords: Deed of Authentic Evidence, Comparative Law, Underhand Agreement.

\section{PENDAHULUAN}

Negara Indonesia terdiri atas pulau-pulau yang terpisah antara satu dengan lainnya, namun aturan pemerintah yang dibuat berlaku di semua daerah mulai dari pedalaman sampai perkotaaan. Hukum di 
buat untuk ditaati dan dipahami sebagai membatasi tingkat laku manusia agar tidak semena-mena terhadap diri sendiri atau orang lain. Aturan yang ketat serta berubah -ubah sepanjang tahun mengikuti perkembangan jaman membuat rakyat semakin mematuhi aturan yang di buat perintah serta sanksi yang juga mengikuti perkembangan jaman sebagai per hatian bagi masyarakat agar tidak melanggar peraturan atau hu kum positif.

Sebagai negara hukum Indonesia memberlakukan hukum tanpa pandang bulu, aturan dan sanksi yang diberikan tidak rnengenal status sosial dan ekonoini, muda tua, kaya dan miskin. Hukum sendiri sudah menjadi batasan bagi seseorang yang ingin menguasai harta benda orang lain, hak seseorang atau bahkan nyawa seseorang dengan berulah sebagai orang yang melakukan tindak pidana. Hukuman yang tegas diberlakukan terhadap perilaku tindak pidana, tujuannya agar negara menjadi aman dan rakyat sejahtera menjalani aktifitas tanpa mengkhawatirkan keamanan dirinya jika berada di luar lingkungan rumahnya.

Kontak yang sering terjadi antar sesama mas yarkat mengakibatkan terjadinya hubungan hukum seminal transaksi di swalayan, atau negosiasi bisnis yang setiap hari pasti terjadi. Kesepakatan antara kedua belah pihak atau lebih didasari keinginan mendapatkan sesuatu atau hak. Hak seseorang dapat diperoleh bila kit a melakukan kewajiban atau interaksi dengan pihak lainn ya biasa disebut hubungan hukum perdata. Tetapi tidak semua hak dan kewajiban dapat direncanakan sebagaimana kesepakatan pasti ada saja salah satu pihak atau individu tidak menggubris kesepakatan membuat perselisihan antar pihak hingga terjadi wan prestasi. Terjadi ingkar janji sudah menjadi hal biasa dalam sebuah perjanjian, perlu di ingat sebesar apapun permasalahan yang terjadi dapat diselesaikan dengan kepada dingin tanpa perlu di besar besarkan. Bisa tidak bisa diselesaikan secara kekeluargaan maka dipersilahkan mengadukan tuduhan ke pengadilan agar mendapatkan kebenaran real. Aduan melalui pengadilan secara langsung tidak efisien karena menghabiskan banyak waktu dan biaya yang sebenarnya bisa dipergunakan untuk kepentingan yang lain.

Adanya kepastian hukum didapat kedua belah pihak membuat masyarkat merasa aman dan tenang karena sanksi diperikan pada pihak yang tepat dan hukuman yang berat serta hukuman tambahan diterima berupa denda. Apabila selama masa kurungan tidak dapat melunasi hutang-hutangnya maka barang milik tersangka akan disita lalu digadaikan sebagai pembayaran denda (Sugiarto, 2015). Peraturan- peraturan yang ada di pengdilan harus dipatuhi tanpa ada yang mangkrak atau tidak hadir jika di minta sebagai saksi atau terduga tersangka oleh majelis hakim. Pengadilan juga harus tegas tanpa melupakan tugas masing-masing agar masyarakat menjadi percara pada hukum positif saat ini (R. Wirjono Projodikoro, 2009).

Peraturan-peraturan yang ada di pengdilan harus dipatuhi tanpa ada yang mangkrak atau tidak hadir jika di minta sebagai saksi atau terduga tersangka oleh majelis hakim. Pengadilan juga harus tegas tanpa melupakan tugas masing-masing agar masyarakat menjadi percara pada hukum positif saat ini (Projodikoro, 2009). Tugas seorang hakim sebagai pemutus atau memberi putusan kepada konflik yang terjadi antara para pihak bersangkutan. Putusan diberikan secara adil dan tidak memihak ke salah satu pihak lainnya tanpa bersama hasil diskusi antar pengadil di pengadilan serta secara tegas menjatuhkan hukuman pada pihak yang terbukti bersalah tanpa merubah hasil putusan. Hakum memutus suatu perkara harus berdasarkan aturan yang berlaku di Indonesia agar masyarakat yakin bahwa hukum yang ada di negara berkembang ini sudah tersusun dan terencana selain sebagai alat pemersatu bangsa.

Sebelum membuat perjanjian kedua pihak agar mendiskusikan isi dari surat perjanjian yang dipergunakan tujuannya agar tidak terjadi wan prestasi atau ada salah satu pihak tidak terima atas hasil kesepakatan. Fungsi surat selain sebagai pengesahan perjanjian dapat difungsikan sebagai alat bukti dalam persidangan. Surat sebagai alat pembuktian adalah bagian terpenting disebuah sidang perkara perdata dimana surat dapat membuktikan bahwa seseorang melakukan kesalah atau melakukan wan prestasi atas perbuatannya sendiri. Terkadang seseorang dapat tertipu dengan surat palsu yang diberikan sebagai bukti atau jaminan. Tujuannya agar mendapatkan keuntungan namun memberikan surat orang lain. Demikian supaya selalu memper hatikan objek dan surat -surat penunjang kesepakatan sebelum kemudian hari menyesal karena tertipu.

Perbandingan kekuatan hukum alat bukti akta otentik dengan akta bawah tangan yaitu aktanya 
dibuat oleh maupun dihadapan pejabat yang berwenang untuk itu didalam wilayah kerjanya sebagaimana diatur dalam undang-undang serta merupakan alat bukti yang sempurna sebagaimana terdapat dalam Pasal 1870 KUHPer sehingga tidak diperlukan lagi alat bukti lainnya dan bagi hakim itu merupaka bukti wajib (verplicht bewijs). Sedangkan akta bawah tangan yaitu aktanya dibuat sendiri tidak dihadapan pejabat yang berwenang dalam undang-undang dan tidak dibuat dalam bentuk yang ditentukan oleh undang-undang serta merupakan "bukti bebas" karena memiliki kekuatan pembuktian materiil setelah dibuktikan kekuatan formilnya sedangkan kekuatan formilnya baru terjadi, bila pihak-pihak yang bersangkutan mengetahui akan kebenaran isi dan cara pembuatan akta tersebut (Darmawa et al., 2021). Kekuatan pembuktian akta di bawah tangan dalam perkara perdata, sepanjang akta di bawah tangan tidak disangkal atau dipungkiri oleh para pihak maka akta di bawah tangan memiliki kekuatan hukum yang sama dengan akta otentik, sedangkan apabila kebenaran tanda tangan dalam akta di bawah tangan di sangkal akan kebenarannya maka akta tersebut harus kebenarannya dengan menggunakan alat bukti yang lain seperti saksi, persangkaan dan pengakuan. Akta di bawah tangan adalah akta yang dibuat tanpa bantuan pejabat umum, melainkan dibuat dan ditandatangani oleh para pihak saja (Palit, 2015). Akta yang dibuat dibawah tangan adalah suatu tulisan yang memang sengaja untuk dijadikan alat bukti tentang peristiwa atau kejadian dan ditandatangani, maka di sini ada unsur yang penting yaitu kesenjangan untuk menciptakan suatu bukti tertulis dan penandatanganan akta itu. Keharusan adanya tanda tangan adalah bertujuan untuk memberi ciri atau untuk menginvidualisir suatu kata (Lusy, 2012).

Dari hasil pemaparan diatas disimpulkan tujuan dari penelitian ini untuk mengetahui perbandingan kekuatan hukum alat bukti akta otentik dengan akta bawah tangan, serta untuk mengetahui pertimbangan hakim dalam putusannya atas kekuatan hukum akta bawah tangan yang mengalahkan akta otentik.

\section{METODE PENELITIAN}

Penelitian skripsi ini dilakukan dengan rnencari data melalui buku ilmu hukun dan menghubungkan dengan permasalahan yang diangkat kemudian mengkaitkan dengan perundang -undangan yang berlaku saat ini. Dari segi hukum penelitian ini termasuk penelitian normatif (Waluyo, 2002). Penulis mengkaitkan dengan peraturan yang berlaku dan tidak menyirnpang dari undang-undang dasar. Pendekatan penelitian dengan cara mengkaji, mencari dan memilah data dari berbagai bukum hukum dan berpatokan pada undang-undang sebagai dasar penulisan penelitian. Penelitian ini bertujuan mencari informasi yang akurat dengan mempelajari gejala masyarakat untuk mendapatkan data yang sebenarbenarnya. Dengan demikian data dapat digabungkan dengan berbagai referensi buku hukum yang terkait dan menghasilkan penelitian yang tidak melenceng dari hukum positif (Ahmad, 2008). Penulis meneliti kasus ini menggunakan metode normatif. Dimana dalam pengerjaannya penulis mengumpulkan informasi dengan menelaah dan menganalisa buku -buku hukum yang didasari peraturan -peraturan hukum yang berlaku di Indonesia.

\section{HASIL PENELITIAN DAN PEMBAHASAN}

\section{Perbandingan Kekuatan Hukum Alat Bukti Akta Otentik Dengan Akta di Bawah Tangan}

Sebagai sebuah surat yang biasanya dipergunakan seseorang dalam perjanjian, Akta biasnya dibuat oleh pegawai yang memiliki wewenang untuk membuat nya dan disaksikan oleh kedua belah pihak yang melakukan perjanjian disamping kedua belah pihak terdapat juga ahli waris bertugas untuk melanjutkan perjanjian yang di buat oleh para pemberi waris. Biasanya perjanjian dengan jarak waktu panjang memilih ahli waris jika hanya sewa menyewa toko atau kendaraan tidak memerlukan ahli war is namun dilihat dari pihak yang melakukan perjanjian apakah kedua belah pihak cakap atau usia masih memadai dalam membuat perjanjian jika tidak perjanjian tidak dapat dilanjutkan karena melanggar syarat sah perjanjian yang di buat pemerintah sebagai acuan masyarakatnya dalam berkontrak.

Penjelasan mengenai akta dibawah tangan merupakan akta yang dibuat berdasarkan kesepakatan para pihak. Akta tersebut disahkan oleh para pihak dengan cara ditandatangani serta didiskusikan secara seksama tanpa ada paksaan dari pihak-pihak terkait. Sahnya suatu akta atau perjanjian tidak ditentukan 
berdasarkan bentuk akta, tetapi ditentukan dari pemenuhan kondisi hukum Perjanjian (jika akta tersebut dalam bentuk perjanjian yang dibuat antara kedua pihak) (Harefa \& Tuhana, 2016). Akta otentik merupakan komponen penting dalam perjanjian, fungsi akta otentik sebagai alat bukti yang mengikat para pihak yang berkontrak didalamnya tedapat isi perjanjian serta hak dan kewajiban masing-masing pihak di buat oleh pejabat yang memiliki skil dibidangnya serta memiliki kekuatan hukum tetap.

Orang yang memiliki wewenang membuat akta otentik disebut notaris. Surat yang harus dimiliki oleh setiap pihak yang melakukan perjanjian agar mengantisipasi terjadinya wan prestasi dikemudian hari. Notaris membuat sebuah surat terdapat bentuk akta dengan penjabaran sebagai berikut : Akta relaas merupakan akta yang tidak memiliki komparisi. Akta tersebut sering disebut akta pejabat dibuat sedemikian rupa oleh pejabat berwenang, secara garis besar segala sesuatu yang berkaitan dengan perjanjian dijelaskan langsung oleh pejabat serta di tulis pada akta tersebut mengakibatkan tanggung jawab besar dipegang oleh notaris itu sendiri atau segal a sesuatu yang berkaitan dengan akta yang di buat semua menjadi tanggung jawab notaris.

Akta pada umurnnya yang biasa disebut sebagai akta notaris yang dibuat berdasarkan kesepakatan para pihak yang berkontrak. Di buat berdasarkan permintaan pihak yang bersangkutan secara sepakat, terdapat komparisi dalam akta tersebut membuat notaris harus mengikuti perintah para pihak yang bersangkutan terkait isi akta tersebut. Menjadi tanggung jawab para pihak apabila kemudian hari terjadi wanprestasi. Tugas seorang pejabat notaris hanya sampai membuat akta maka harus dipertimbangkan secara matang isi dari akta yang ingin di buat (Sjaifurrachman \& Adjie, 2011). Terdapat kelemahan antara akta yang dibuat oleh pejabat berwenang yaitu akta notaris yang dibuat oleh pejabat berwenang sekaligus bertanggung jawab atas akta tersebut tidak dapat di gugat kepengadilan namun keleluasaan para pihak tidak didapat dalam akta tersebut. Akta relaas bisa dituntut namun atas dasar tuduhan pemalsuan akta oleh pejabat notaris. Sedangkan akta yang dibuat pejabat notaris dengan dihadiri para saksi dan pihak bersangkutan dapat di gugat kepengadilan alasannya tanggung jawab atas akta ada ditangan para pihak yang berkontrak sedangkan pejabat notatis hanya sebagai pembuat akta saja. Apapun akta yang dipilih sebagai pengikat perjanjian serta hak kewajiban para pihak harus atas dasar keinginan bersama agar setelah akta di buat tidak terjadi wan prestasi salah satu pihak karena merasa tidak sesuai keinginan. Pembuatan akta harus dilakukan secara matang menggunakan kepala dingin lebih baik perdebatan terjadi di saat akta akan di buat daripada perdebatan terjadi saat proses kontrak telah berlangsung.

\section{Pertimbangan Hakim Dalam Putusannya Atas Kekuatan Hukum Akta Bawah Tangan yang Mengalahkan Akta Otentik}

Penjelasan mengenai akta dibawah tangan merupakan akta yang dibuat berdasarkan kesepakatan para pihak. Akta tersebut disahkan oleh para pihak dengan cara ditandatangani serta didiskusikan secara seksama tanpa ada paksaan dari pihak-pihak terkait. Tujuan akta dibawah tangan sebagai pengikat para pihak yang melakukan perjanjian dengan mengambil prinsip kepercayaan yang secara bersama-sama membuat serta mengesahkan akta sebagai bukti telah dibuat kesepatakan antara kedua belah pihak. Terdapat ketentuan kewajiban dan hak para pihak dalam akta tersebut serta sanksi bagi pihak yang sengaja melanggar isi perjanjian. Akta dibawah tangan ditandatangani para pihak dihadapan notaris dimana disaksikan minimal dua saksi bisa dari pegawai notaris atau dari masing -masing pihak yang berkontrak. Sedangkan akta otentik merupakan akta yang biasanya para pihak menjadikan diri sendiri sebagai flat bukti maka disebut akta yang sempurna. Apabila masih ada pihak yang meragukan akta otentik maka dipersilahkan menilai melalui kekuatan pembuktian for mil, lahiriah, dan materiil. Penjabaran pembuktian akta otentik secara tingkat sebagai berikut :

Pembuktian lahiriah merupakan perbedaan paling signifikan antara akta otentik dan dibawah tangan, karena akta otentik tanpa alat bukti lain sudah bisa membuktikan dirinya. Akta ini merupakan akta bersifat sempurna karena sudah memenuhi syarat sahnya perjanjian jadi tidak ada seorang atau pihak manapun dapat menyangkal kebenaran akta ini. Berbeda dengan akta dibawah tangan jika ada pihak yang keberatan maka dapat di adukan ke pengadilan.

Akta lahiriah adalah akta yang secara hukum sudah memiliki ketentuannya sendiri tentang syarat 
sah perjanjian, segala berkas dapat dibuktikan kebenarannya mulai dari cover sampai dengan penutup atau akhir kata dengan demikian akta ini secara otomatis mampu membuktikan keabsahannya.

Akta otentik dilihat melalui aspek lahiriah merupakan akta yang tidak perlu dipertan yakan lagi kebenarannya. Apabila dikemudian hari ada tuntutan bahwa akta ini tidak memenuhi syarat maka pihak yang bertanggungjawab wajib membuktikan keasliannya. Penggugatan terhadap akta otentik dapat disangkal atau dibuktikan kebenarannya melalui pengadilan.

Pembuatan akta notaris dibuat secara terbuka dihadiri oleh para pihak yang bersangkutan bersama para saksi, harus sesuai prosedur pembuatan akta, diperhatikan secara seksama penulisan tanggal, bulan, para pihak yang menghadap, para saksi, tanda tangan para pihak, tahun dibuat akta serta pendapat dari para pihak atau isi perjanjian dari akta otentik. Sebagai pihak yang akan melakukan pembuatan akta harus teliti setiap komponen -komponen yang berkaitan dengan pembuatan akta supaya setelah ditandatanganinya akta oleh kedua belah pihak dapat terlakasana dengan baik tanpa terjadinya wan prestasi dikarenakan salah satu pihak ada yang kurang sependapat saat diskusi terkait hak dan kewajiban para pihak dalam berkontrak.

\section{SIMPULAN DAN SARAN \\ 1. Simpulan}

Dari pemaparan penelitian diatas dapat disimpulkan bahwa perbandingan kekuatan hukum alat bukti akta otentik dengan akta bawah tangan yaitu aktanya dibuat oleh maupun dihadapan pejabat yang berwenang untuk itu didalam wilayah kerjanya sebagaimana diatur dalam undang-undang sertaCmerupakan alat bukti yang sempurna sebagaimana terdapat dalam Pasal 1870 KUHPer sehingga tidak diperlukan lagi alat bukti lainnya dan bagi hakim itu merupakan bukti wajib erpli<ht 6rniy.t). Sedangkan akta bawah tangan yaitu aktanya dibuat sendiri tidak dihadapan pejabat yang berwenang dalam undang- undang dan tidak dibuat dalam bentuk yang ditentukan oleh undang-undang serta merupakan "bukti bebas" karena memiliki kekuatan pembuktian materiil setelah dibuktikan kekuatan formilnya sedangkan kekuatan formilnya baru terjadi, bila pihak-pihak yang bersangkutan mengetahui akan kebenaran isi dan cara pembuatan Akta tersebut. Pertimbangan Hakim dalam putusannya atas kekuatan hukum akta bawah tangan yang mengalahkan akta otentik yaitu bahwa didalam melakukan transaksi jual beli yang sah adalah tidak dapat dilihat hanya dari dimana perjanjian jual beli tersebut dibuat, melainkan harus juga dilihat dari segi penyerahan (leerinp) obyek jual beli tersebut karena berdasarkan pasal pasal 1459 K UHPer Hak milik atas suatu benda hanya akan beralih kepada pembeli apabila barang yang dibeli itu diserakan oleh penjual ke pembeli. Walaupun pada kenyataannya penggugat asal dan penggugat intervensi sudah membayar lunas obyek tersebut tetapi yang menempati obyek tersebut adalah penggugat asal. Apabila dalam pembuatan akta dibawah tangan telah diakui secara seksama oleh para pihak maka setara dengan akta otentik terkait pembuktian keasliannya.

\section{Saran}

Disarankan bagi masyarakat yang hendak melakukan perjanjian jual beli secara dibawah tangan diharapkan untuk lebih berhati-hati, cermat dan teliti dalam membuat surat perjanjian jual beli yang berisi pasal-pasal yang dituliskan dalam sebuah akta dibawah tangan, karena semua perjanjian yang dibuat secara sah berlaku sebagai undang-undang bagi mereka yang mernbuatnya serta diharapkan dapat memahami dengan benar apa isi serta maksud pasal-pasal yang hendak mengikat tersebut. Selain itu disarankan juga jika ingin membeli suatu obyek ada baiknya kita memeriksa obyek tersebut terlebih dahulu seperti melihat siapa yang menempati dan asal usul obyek tersebut Disarankan bagi Pengadilan bahwa hakim harus lebih teliti dalam memeriksa permasalahan yang berkaitan dengan hal ini terutama dalam proses pembuktian karena bisa saja legalisasi bersumber dari dokumen atau keterangan palsu serta alangkah baiknya pula dalam hal pemeriksaan di sidang pengadilan, hakim harus memanggil pihak-pihak yang bersangkutan agar dapat dimint a keterangan mengenai permasalahan akta tersebut. Selain itu hakim juga harus memperhatikan Peraturan Pemerintah Nomor 24 Tahun 1997 Pasal 37 bahwa peralihan hak atas tanah hanya dapat didaftarkan jika dibuktikan dengan akta yang dibuat oleh PPAT. 


\section{DAFTAR PUSTAKA}

Waluyo, B. (2002). Penelitian Hukum Praktik (cet. 3). Sinar Grafika. Jakarta.

Ahmad, B. (2008). Metode Penelitiain Hukum. Pustaka Setia. Bandung.

R. Wirjono Projodikoro. (2009). Hukum Acara Perdata Indonesia. Bina C ipta. Bandung.

Sjaifurrachman, \& Adjie, H. (2011). Aspek Pertanggungjawaban Notaris dalam Pembuatan Akta. CV. Mandar Maju. Bandung.

Sugiarto, U. S. (2015). Pengantar Hukum Indonesia. Sinar Grafika. Jakarta.

K.F.R, L., \& Garungan. (2012). Kekuatan Pembuktian Akta si Bawah Tangan yang Telah Memperoleh Legalitas dari Notaris. Untrat Repository, Vol.2(1).

Palit, R. C. (2015). Kekuatan Akta Di Bawah Tangan Sebagai Alat Bukti Di Pengadilan. Lex Rivantum, Vol.3(2).

Darmawa, R., Dewi, A. A. S. L., \& Karma, N. M. S. (2021). Perbandingan Kekuatan Hukum Alat Bukti Otentik Dan Perjanjian Bawah Tangan (Studi Kasus Perkara Nomor: 939/Pdt.G/2018/Pn Dps). Kontruksi Hukum, Vol.2(1).

Projodikoro, R. W. (2009). Hukum Acara Perdata Indonesia. Bandung: Bina Cipta.

Harefa, B. D. S., \& Tuhana. (2016). Kekuatan Hukum Perjanjian Lisan Apabila Terjadi Wanprestasi (Studi Putusan Pengadilan Negeri Yogyakarta Nomor 44/PDT.G/2015/PN.YYK). Privat Law, IV(2). 